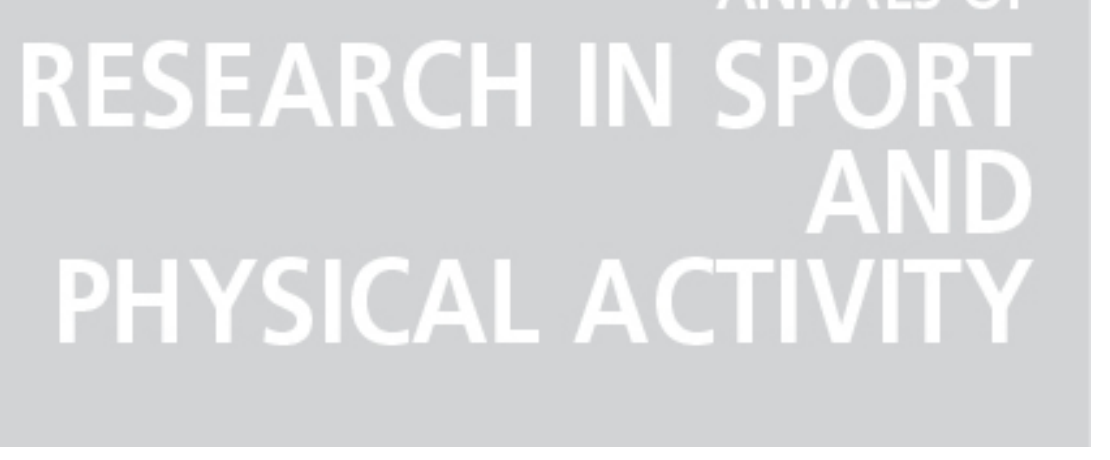

\title{
Exercise and the brain
}

Autor(es): Meeusen, Romain

Publicado por: Imprensa da Universidade de Coimbra

URL

persistente:

URI:http://hdl.handle.net/10316.2/44065

DOI:

DOI:https://doi.org/10.14195/2182-7087_ex2018_2

Accessed : $\quad$ 26-Apr-2023 03:07:21

A navegação consulta e descarregamento dos títulos inseridos nas Bibliotecas Digitais UC Digitalis, UC Pombalina e UC Impactum, pressupõem a aceitação plena e sem reservas dos Termos e Condições de Uso destas Bibliotecas Digitais, disponíveis em https://digitalis.uc.pt/pt-pt/termos.

Conforme exposto nos referidos Termos e Condições de Uso, o descarregamento de títulos de acesso restrito requer uma licença válida de autorização devendo o utilizador aceder ao(s) documento(s) a partir de um endereço de IP da instituição detentora da supramencionada licença.

Ao utilizador é apenas permitido o descarregamento para uso pessoal, pelo que o emprego do(s) título(s) descarregado(s) para outro fim, designadamente comercial, carece de autorização do respetivo autor ou editor da obra.

Na medida em que todas as obras da UC Digitalis se encontram protegidas pelo Código do Direito de Autor e Direitos Conexos e demais legislação aplicável, toda a cópia, parcial ou total, deste documento, nos casos em que é legalmente admitida, deverá conter ou fazer-se acompanhar por este aviso. 


\section{ANNALS OF RESEARCH IN SPORT AND PHYSICAL ACTIVITY}




\title{
REGULATION OF MUCOSAL IMMUNUTY AND IMPACT OF EXERCISE
}

\author{
Maree Gleeson ${ }^{1}$
}

KEY WORDS: mucosal immunity, exercise, salivary IgA, infections, inflammation, microbiome

The first research on the impact of exercise on mucosal immunity was published by Tomasi et.al ${ }^{(1)}$ thirty-five years ago on the changes in salivary IgA concentrations before and after strenuous exercise in high-performance athletes. There have been many investigations since on the impact of exercise on salivary $\lg A$ in different populations, spaning elite to sedentary, young and old, obese and healthy weight, differences in responses between males and females, and across many sports ${ }^{(2,3)}$. Much of this research has focused on the role of mucosal immunity in prevention of mucosal infections and use of salivary IgA as a marker to predict athletes at higher risk of upper respiratory illness (URI)(3), or in some situations as a marker for acute and chronic stress responses ${ }^{(4)}$. Depending on the populations being studied the utilisation of salivary $\lg A$ as a predictor of risk of infections has been variable. However, the consensus is that clinically low levels of salivary IgA place a person at increased risk of respiratory infections ${ }^{(3)}$, and changes in S-IgA in response to psychological stress are consistent with increases in response to acute stress, and a decrease over time in response to chronic stressors ${ }^{(4)}$.

While recognising the importance of effective mucosal immunity as the first-line-ofdefence against infections, there has been very little research on the impact of exercise on regulation of the mucosal immune system in humans. Research on immune regulation with exercise has been predominantly confined to animal models, mainly due to the difficulty and ethics of undertaking similar investigations in humans. The transferability of animal research to humans is not always perfect and needs to be considered with caution before being implemented as 'dogma' for advice to exercising humans.

\footnotetext{
1 Faculty of Health \& Medicine, University of Newcastle, Australia
} 


\section{REGULATION OF HUMAN MUCOSAL IMMUNITY}

The following summary relies heavily on the consensus information published in the latest edition of Mucosal Immunology $y^{(5)}$.

Control of mucosal immunity

Effective mucosal immunity relies on the uptake, processing and presentation of antigens that discriminates between harmless antigens and dangerous pathogens or their toxins ${ }^{(6)}$. A primary role is the production of humoral and cellular factors of innate and specific immunity that prevents overstimulation of the immune system and disruption of the mucosal membrane integrity. The mucosal immune system interacts in a continuous bidirectional manner with the microbiota to ensure an appropriate response that is tightly controlled by anti-inflammatory mechanisms.

The integrity of the epithelial cells lining mucosal surfaces is critical to effective immunity. The tight intercellular junctions, mucociliary actions, physiochemical barriers, and microbial pattern recognition receptors on the epithelia, are all important functions and critical for health. The epithelium is a source of innate humoral factors in the human intestinal and respiratory tracts. While initially pro-inflammatory to attract and activate myeloid and lymphoid cells, the rapid switch to immunosuppressive cytokines (IL-10, TGF-B) and chemokines is necessary to minimise tissue damage. The epithelium plays a key role in noninflammatory antigen disposal via the polymeric-lgA (plgA) interacting with the polymeric immunoglobulin receptor (plgR) on epithelial surfaces.

Dendritic cells (DCs) in the lamina propria or protruding into the lumen between epithelial cells influence the recruitment and differentiation of lymphoid cells. Migration of DCs to the regional lymph nodes induces mucosal T-helper cell (Th17) responses that produce cytokines (IL-17 and IL-22) upregulating S-IgA production, epithelial cell production of antimicrobial proteins and peptides, and plgR expression. The majority of mucosal T-cells (CD4 and CD8) display phenotypes that are important in rapid cytotoxic responses to infections, particularly virally infected epithelial cells.

Regulation of mucosal defence, immune tolerance to non-pathogenic antigens and maintenance of epithelial barrier integrity by non-inflammatory mechanisms involves intricate interactions between mucosal cellular populations to maintain homeostasis. In addition to innate mucosal lymphoid cells, the T-regulatory cells, produced in the gut-associated lymphoid tissues (GALT) and mesenteric lymph nodes play key roles in controlling inflammation and ensuring epithelial cell growth and repair.

\section{Transfer of immunity via CMIS}

Immune responses can be induced locally at all mucosal surfaces in response to local antigen presentation. An important feature of the integrated common mucosal immune system (CMIS) is the ability to confer protective immunity at distant mucosal sites by the 
transfer of cells from inductive sites, particularly the respiratory and intestinal tracts ${ }^{(6)}$. The transfer of T-cells from inductive sites provides rapid effector mechanisms at distant mucosal sites, and in addition to protective antibodies in human milk, passive protection of newborns.

As much of the research on the impact of exercise on mucosal immunity has focused on the respiratory tract it is worth commenting on the nasal and bronchial immune systems. The structure of lymphoid tissues in the nasal and oral cavities, and respiratory tract differs between humans and rodents ${ }^{(7)}$. Unlike rodents, nasal-associated lymphoid tissue (NALT) and bronchus-associated lymphoid tissues (BALT) are not present in every individual and the clusters have a random distribution that is only evident following infection or inflammation. Human NALT and BALT can promote IgA-producing B-cells in response to infections but also prime IgG-producing B-cells in the nasal passage and lung. In response to inhaled allergens NALT and BALT can induce IgE-producing B-cell responses. The dendritic cell and T-cell responses to antigen in NALT and BALT and respiratory tract induce strong cytotoxic T-cell responses that have long-lived memory, and are critical for killing virus-infected epithelial cells. Rapid control of viral reactivation is important particularly in respiratory lymphoid cells with latent viruses such as Epstein Barr Virus (EBV).

\section{Influencing factors}

The major factors influencing mucosal immune responses are commensal bacteria and pathogen exposure. The ability to maintain mucosal homeostasis and health are influenced by the following key factors in humans:

- Genetic inheritance can influence the regulation of the immune response or tissue repair necessary to avoid inappropriate or uncontrolled inflammatory responses.

- The microbiome is impacted by nutrition, probiotic and antibiotic treatments not only in the gastrointestinal tract but at other mucosal sites leading to altered immune responses.

- Nutritional deficits of important macro- and micro-nutrients can lead to impaired immune responses.

- Mucosal infections and allergens can alter immune responses that result in chronic inflammatory responses or disturbed mucosal epithelial barrier functions, despite appropriate therapeutic interventions

- Neuronal regulation and stress responses are critical to effective immune response at mucosal sites $^{(8)}$ not only to infections but other psychological and environmental stressors ${ }^{(4)}$. The bidirectional interactions between the nervous and immune systems, and the modulating effects of commensal bacteria, regulate the 'gut-brain' communication mechanisms controlling inflammatory responses and epithelial barrier functions. 


\section{IMPACT OF EXERCISE ON HUMAN MUCOSAL IMMUNITY}

The impact of exercise on the regulation of the mucosal immune system in humans is not well studied. The limited information available is often inferred from indirect measures or animal studies.

\section{Genetic influences and cytokine responses}

Ethnicity impacts on the genetic inheritance of cytokine regulation ${ }^{(9)}$. Differences in cytokine gene polymorphisms and responses to exercise suggest a genetic predisposition to pro-inflammatory responses in athletes who are prone to URI, and who have impaired regulation of cytokine responses to exercise ${ }^{(10)}$.

A defect in IFN-y secretion ${ }^{(11)}$ has also been associated with athletes experiencing recurrent URI and fatigue, consistent with differences observed in IFN- $y$ genotypes ${ }^{(12)}$.

\section{Mucosal antibodies}

The impact of exercise on salivary IgA responses is the most extensively studied field of mucosal immunity ${ }^{(2,3,10)}$ but the impact on the regulation of S-IgA has not been directly investigated. The consensus indicates that changes in salivary IgA concentrations vary with the intensity of exercise, and sustained reductions are predominantly seen in high-intensity endurance training. As in the general population, low levels of salivary $\lg A$ are associated with an increased risk of URI in high-performance endurance athletes ${ }^{(2,3)}$. Moderate exercise can increase salivary IgA levels and training modifications incorporating this impact can be effective in reducing the incidence of $U R^{(113)}$.

S-IgA concentrations in tear fluid can be predictive of URI in athletes ${ }^{(14)}$. Gut immunity has predominantly been studied in healthy exercising populations in relation to nutritional and probiotic interventions (discussed below) or disruption of epithelial barriers during intense exercise ${ }^{(15)}$. Long duration strenuous exercise in the heat can cause increased intestinal permeability and disruption of pathogen responses in humans ${ }^{(16)}$.

\section{Vaccination responses}

The impact of exercise on mucosal vaccine responses, as opposed to systemic vaccinations, indicates high performance athletes are capable of mounting appropriate responses ${ }^{(17)}$. The timing of the vaccination in relation to exercise can boost the response ${ }^{(18)}$. 


\section{Nutrition and probiotics}

The impact of macro- and micro-nutrients on immunity has recently been reviewed in exercising populations ${ }^{(19)}$ and a balance of all key nutrients is required for effective mucosal immunity. There are no studies on immune regulation at mucosal surfaces in humans.

Similarly, probiotic interventions ${ }^{(19)}$ have focused on maintaining a 'healthy' profile of microbiota at gastrointestinal surfaces based on the assumptions of animal studies and interactions between the commensal bacteria, mucosal immune responses and the integrity of epithelial barriers ${ }^{(20)}$. While human studies are limited, exercise per se and interactions with dietary intake can alter the diversity of gastrointestinal microbiota but little is known of the impact on mucosal immune regulation ${ }^{(20)}$.

\section{Innate immune factors}

Lactoferrin and lysozyme concentrations in saliva have been incorporated into human studies and provide insight on the acute response to exercise $(2,15)$. Recently the response of midkine, an endothelial biomarker, indicated a rapid response to intense exercise that resolves rapidly with cessation of exercise ${ }^{(10)}$, suggesting intense exercise induces an acute 'stress' response. The impact of these innate biomarker responses on regulation of specific mucosal immunity is not clear.

\section{Neuronal interactions and stress responses}

Exercise can be a stimulant of a physiological stress response resulting in both positive effects on immune function associated with short term stress responses, and negative effects from prolonged intense exercise, particularly under adverse environmental conditions ${ }^{(18)}$. The impact on mucosal immune function can only be inferred from measures of neuronal responses to exercise, and their interaction with the immune system and mucosal epithelial integrity.

\section{CONCLUSION}

The impact of exercise on regulation of mucosal immune responses in humans is not well understood and studies are difficult to design. Inference from indirect measures and clinical outcomes are currently the only available outcome measures. Animal-based studies require cautious application to humans. 


\section{REFERENCES}

1. Tomasi TB et al. (1982), "Immune parameters in athletes before and after strenuous exercise". J Clin Immunol. Vol. 2, pp. 173-178.

2. Walsh NP et al. (2011), "Position statement Part One: Immune function and exercise", Exerc Immunol Rev, Vol. 17, pp. 6-63.

3. Gleeson M \& Pyne DB. (2016), "Respiratory inflammation and infection in high-performance athletes" Immunol Cell Biol, Vol. 94, pp. 124-131.

4. Bosch JA et al. (2002), "Stress and secretory immunity", Int Rev Neurobiol, Vol. 52, pp. 213-253.

5. Mestesky J et al. (2015), "Mucosal immunology", Elsevier Academic Press, Oxford, UK. $4^{\text {th }}$.

6. Russell MW et al. (2015), "Overview: The mucosal immune system" In: Mucosal immunology. Edited by Mestesky J et al. Elsevier Academic Press, Oxford, UK. $4^{\text {th }}$ Ed, Vol 1. Ch 1, pp3-8.

7. Randall TD. (2015), "Structure, organization, and development of the mucosal immune system of the respiratory tract" In: Mucosal immunology. Edited by Mestecky J et al. Elsevier Academic Press, Oxford, UK. $4^{\text {th }}$ Ed, Vol 1. Ch 4, pp. 43-61.

8. De Jonge WJ. (2015), "Neuronal regulation of mucosal immune responses. In: Mucosal immunology" Edited by Mestecky J et al. Elsevier Academic Press, Oxford, UK. 4 ${ }^{\text {th }}$ Ed, Vol 1. Ch 46, pp. 929-942.

9. Scott RJ et al. (2006), "The influence of infection on cytokine gene polymorphisms in evolution. In: Before Farming. Pandanus Press, ANU, Australia, pp1-7.

10. Gleeson M et al. (2017), "Developing a multicomponent immune model for evaluating the risk of respiratory illness in athletes. Exerc Immunol Rev. Vol. 23, pp. 54-66.

11. Clancy RL et al. (2206), "Reversal in fatigued athletes of a defect in interferon $\nabla$ secretion after administration of Lactobacillus acidophilus", Brit J Sports Med, Vol. 40, pp. 351-354.

12. Vollmer-Conna $U$ et al. (2008), "Cytokine polymorphisms have a synergistic effect on severity of acute sickness response to infection", Clin Infect Dis. Vol. 47, pp. 1418-1425.

13. Gleeson M et al. (2000), "Salivary immunoglobulin monitoring in an elite kayaker", Clin J Sport Med., Vol.10, pp. 206-208.

32 14. Hanstock HG et al. (2016), "Tear fluid SIgA as a noninvasive biomarker of mucosal immunity and common cold risk", Med Sci Sports Exerc. Vol. 48, pp. 569-577.

15. Walsh NP et al. (2011), "Position Statement Part Two: Maintaining immune health" Exerc Immunol Rev. Vol. 17, pp. 64-103.

16. Zuhl M et al. (2014), "Exercise regulation of intestinal tight junction proteins" Br J Sports Med. Vol. 48, pp. 980-986

17. Gleeson M et al. (1998), "Salmonella typhi vaccine response in elite swimmers". Int J Sports Med. Vol.19, Ch. 3, 218.

18. Dhabhar FS. (2014), "The effects of stress on immune function: the good, the bad, and the beautiful" Immunol Res, Vol. 58, pp. 193-210.

19. Berman S et al. (2017), "Consensus Statement: Immunonutrition and exercise", Exerc Immunol Rev, Vol. 23, pp. 8-50.

20. Campbell SC \& Wisniewski PJ. (2017), "Exercise is a novel promoter of intestinal health and microbial diversity" Exerc Sport Sci Rev. Vol. 45, pp. 41-47. 